\title{
An investigation of EFL teachers' and learners' attitudes towards product and process approaches to writing
}

\author{
Ghobadi, Mahdieh $\bowtie$ \\ Azad University of Bushehr, Iran (Ghobadi.m27@gmail.com)
}

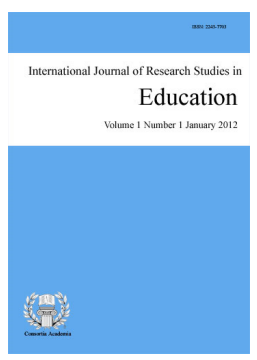

ISSN: 2243-7703 Online ISSN: 2243-7711

OPEN ACCESS

\section{Abstract}

The purpose of the present study is to find out the Iranian EFL learners' and teachers' attitudes toward product and process approaches to writing. To gain this end, 92 intermediate English language learners studying in Caspian language institutes and 25 EFL teachers were selected. Two instruments were used to achieve more accurate answers to the research questions; a questionnaire and an interview. Upon an extensive literature review and having interviews with the participants, the researcher developed two sets of 5-point Likert-scale questionnaires, one for teachers (20 items) and one for learners (23 items $\neg$ ) to investigate the participants' attitudes toward the two approaches. The items of the questionnaires were categorized into three categories: general questions, features of product approach, and features of process approach. The researcher used descriptive statistics to investigate the participants' attitudes toward the approaches. Based on the results of the descriptive analysis of the participants' responses it is concluded that most of the teachers $(69.2 \%)$ and learners $(64.32 \%)$ have positive attitude towards process approach.

Keywords: product approach; process approach; EFL writing; attitude 


\section{An investigation of EFL teachers' and learners' attitudes towards product and process approaches to writing}

\section{Introduction}

Traditionally, teaching writing has been language-focused. Viewed essentially as secondary and in some senses inferior to the spoken language, writing was used as a means of reinforcing language. So, the learners' writing abilities were not satisfactory. But recently writing got more attention as an important language skill for both learners and teachers. Researchers and curriculum planners also tried to discover the true nature of writing and how it can be taught effectively. They sought to find the best methods and approaches to improve the learners' writing.

Over time different approaches have been introduced in language classrooms. Initial approaches to English as a Foreign Language (EFL) and English as a Second Language (ESL) writing instruction was replications of first language writing instruction (Vanderpy, 2012). Before1970s, the traditional approach (product approach) was applied in the writing classrooms. The growing dissatisfaction with product approach to teaching writing coincided with a growing interest in discovering how writers actually do write (ibid). Back in 1970s and 1980s a shift occurred in the arena of writing process. This was the time when the process writing approaches started to be employed in language classrooms with attention to content prior to form (Palpanadan et al., 2014).

\subsection{Writing skill}

Language is a vital tool for communicating thoughts and ideas and it involves four basic skills, namely; listening, speaking, reading and writing. Among the four basic skills in English, the most complex and difficult skill to master is probably writing; specially writing in a second or foreign language as most of the thinking process is usually carried out in the mother tongue (Al-Sawalha, 2014). As Alodwan and Ibnian (2014) stated, "Writing is no longer viewed as a simple linear activity consisting of several stages that are independent and sequenced. In contrast, writing is now recognized as a complex and integrated set of processes that are interactive and recursive" (p. 5). So, writing involves the creation of ideas and ability to express them logically and coherently (Al Souqi, 2001).

Furthermore, learning to write in English as second or foreign language is of great importance; since it is the global language of communication (Al-Sawalha, 2014). Writing helps students to acquire content knowledge and develop their cognitive skills by analyzing, synthesizing, evaluating and making inferences (Zamel, 1998). Writing needs the ability of solving linguistic problems, so this helps students to develop their second language proficiency (Manchón \& Roca de Larios, 2007). Hence, writing is a complex and intertwined network of the interactive processes; not a linear activity. The following sections clarify different approaches to teaching writing skill.

\section{Review of the literature}

\subsection{Product approach to teaching writing}

The product approach to teaching writing is an approach which demands the students to produce compositions similar to a model essay represented by the teacher (Pincas, 1982). Hence, product approach focuses on the surface structures of writing at the sentence level and gives crucial roles to the cohesion and readability (Yi, 2009). This approach was named differently by different researchers. It was named Product-based approach by Nunan (1999), Controlled composition approach by Silva (1990), Controlled-to-free 
An investigation of EFL teachers' and learners' attitudes towards product and process approaches to writing

approach by Raimes (1983) and Traditional text-based approach by Tribble (1996). Product approach focuses on the learners' final product to be error-free at sentence level and puts emphasis on language form, i.e., grammar, syntax and mechanics (Yi, 2009).

Product approach to writing follows the traits of behaviorism; it means that learning is habit formation and learners imitate and transform models provided by textbooks and teachers (Nunan, 1999; Raimes, 1983; Silva, 1990; Tribble, 1996). So, in this approach, writing, refers to "the ability to adhere to style-guide prescriptions concerning grammar, arrangement and punctuation" (Nunan, 1999, p. 59) without considering any role for the context, audience or proccessability (Hyland, 2002). The main weakness of the product approach is that it focuses completely on the final output rather than on the actual writing processes (Kamimura, 2000) and "this may affect negatively the level of command of the writing skills" (Al-Sawalha, 2014, P. 42). Beside of its weakness, this approach has its strength in that it emphasizes grammatical accuracy in the final product (Al-Sawalha, 2014).

\subsection{Process approach to teaching writing}

The process approach to writing emerged due to the criticism on product approach to teaching writing skill in the 1960s (Silva, 1990). This type of approach to writing stresses on the processes the writer goes through during writing (Johns, 1990; Nunan, 1999; Raimes, 1983; Silva, 1993; Tribble, 1996). It is divided into three subcategories: Expressivist, Cognitivist and Social (Situated) strands (Grabe \& Kaplan, 1996; Hyland, 2002; Johns, 1990).

In the Expressive view which emerged in 1960s, teachers encourage students to develop power over their own writing without being directive, assuming that writing is a creative act and that the process is a discovery of the true self (Berlin, 1988). Learners freely express themselves (Grabe \& Kaplan, 1996) and the writing activities are personal essays and journal writing (Johns, 1990). From this point of view, writing ability can be defined as the ability to express oneself freely (Yi, 2009).

The Cognitivist view which emerged in the early 1970s, is the most well-known view of process approach. It stresses the cognitive processes the writer go through which was mostly covered by Hayes and Flower (1981) and Bereiter and Scardamalia (1987) writing models. Generally, there are three main steps in the cognitive view of the process approach, namely, planning, drafting and reviewing. The main weak point of this view, according to Grabe and Kaplan (1996) refers to the fact that Writers are not likely to be uniform with respect to their processing preferences and cognitive abilities; [...] a protocol analysis approach [which was used by Hayes and Flower] may not be a valid primary methodology for the study of the writing process to the extent that Flower and Hayes claim [...] [or at least from a more moderate perspective] it cannot be the primary source of evidence for a theory of the writing process (pp. 92-93).

Social strand of process approach to writing stresses the social context (Hyland, 2002). Hyland (2002) argues that social perspective of the process approach to teaching writing is an integration of the cognitive structures and physical and experiential contexts in which writing occurs. Palpanadan et al. (2014) argue about eight steps in conducting a process approach to teaching writing, namely, brainstorming, planning, mind mapping, first draft, peer feedback, editing, final draft, and evaluation. Hence, in a process approach to teaching writing, teacher plays a facilitator role instead of the model role played by a teacher in product approach to teaching writing (Rasuli, 2015, p. 42). Therefore, writing ability in process approach is defined "as the ability to initiate and evolve ideas and then use certain revising and editing practices to develop them to maturity in a given context" (Yi, 2009. p. 60).

\subsection{Advantages and disadvantages of approaches}

As Badger and White (2000) believed all the approaches have their own deficiencies. The following table demonstrates the advantages and disadvantages associated with the two approaches previously mentioned. 
Ghobadi, M.

Table 1

Advantages and disadvantages of approaches

\begin{tabular}{|c|c|c|}
\hline & Advantage & Disadvantage \\
\hline Product Approach & $\begin{array}{l}\text { It recognizes the need for learners to } \\
\text { be given linguistic knowledge about } \\
\text { texts, and it understands that } \\
\text { imitation is one way in which people } \\
\text { learn. }\end{array}$ & $\begin{array}{l}\text { Process skills, such as planning a text, } \\
\text { are given a relatively small role, and } \\
\text { the knowledge and skills that learners } \\
\text { bring to the classroom are } \\
\text { undervalued. }\end{array}$ \\
\hline Process Approach & $\begin{array}{l}\text { It understands the importance of the } \\
\text { skills involved in writing, and } \\
\text { recognizes that what learners bring } \\
\text { to the writing classroom contributes } \\
\text { to the development of writing } \\
\text { ability. }\end{array}$ & $\begin{array}{l}\text { - regards all writing as being produced } \\
\text { by the same set of processes } \\
\text { - gives insufficient importance to the } \\
\text { kind of texts writers produce and why } \\
\text { such texts are produced } \\
\text { - offers learners insufficient input, } \\
\text { particularly in terms of linguistic } \\
\text { knowledge, to write successfully. }\end{array}$ \\
\hline
\end{tabular}

\subsection{Attitude theory}

Attitude is an important concept of social psychology. So that the "Early psychologists have defined social psychology as the scientific study of attitudes" (Dernoun, 2015, p. 20). There are a number of definitions for the concept of attitude in the literature. Attitude is inferred from behavior and it cannot be directly observed. So, it is a hypothetical construct to explain the direction of human behavior (Dernoun, 2015). Attitude is "a mental and neural state of readiness, organized through experience, exerting a directive and dynamic influence upon the individual's response to all objects and situations with which it is related" (Allport, 1935, p. 810).

According to Travers (1973) attitude can be defined as "a readiness to respond in such a way that behavior is given a certain direction" (p. 337). Also Olson and Maio (2003) defined attitude as "tendencies to evaluate objects favorably or unfavorably" (p.299). Even though there are somehow clear definitions of attitude, it is a confusing concept which is used instead of these terms: opinions, beliefs, interests, and values. "These five interrelated terms are not always distinguished or defined very clearly in the literature" (Dornyei, 2003, p. 9). So, they are explained briefly in following:

Attitude: It concerns evaluative responses to a particular target (e. g., people, institution, situation) which is deeply embedded in the human mind. Since it is rooted back in people's past or modeled by certain significant people around them, it is resistant to change (Dornyei, 2003).

Opinion: Such as attitudes, it is subjective, but it perceived as being more factually based and more changeable. People are always aware of their opinions but they may not be fully conscious of their attitudes (Aiken, 1996).

Belief: It has a stronger factual support than opinion and often concerns the issue that whether something is true, false, or 'right'. (Dornyei, 2003).

Interest: It is preference for particular activities (Dornyei, 2003).

Value: It is of two types; one which concerns preferences for 'life goals' and 'ways of life' (e. g., Christian values) and one which is used to describe the utility, importance, or worth attached to particular activities, concepts, or objects (e. g., instrumental/utilitarian value of L2 proficiency) (Dornyei, 2003). To summarize, it can be said that generally attitude is "a hypothetical construct that represents an individual's like or dislike for an item" (Dernoun, 2015, p. 22). It can be positive, negative or neutral. 
An investigation of EFL teachers' and learners' attitudes towards product and process approaches to writing

\subsection{Related studies}

A number of researches regarding the process and product approaches in teaching writing have been conducted separately in different educational contexts around the world which will be elaborated separately in the following:

Product approach - The most widely and commonly used approach worldwide for teaching writing is product or traditional approach. But there were somehow few researches studying product approach alone. Nordin and Mohammad (2006) studied product approach and mentioned that "proponents of the product approach such as Badger and White (2000, p. 157) argued that it enhances students' writing proficiency and writing involves linguistic knowledge of texts that learners can learn partly through imitation." (p. 78).

Process approach - A number of studies regarding the implementation of the process approach in teaching writing have been conducted in different educational areas related to language teaching in different parts of the world. Most of the researchers studied the effects of process approach on writing skill and presented their results. As the herald of this researches, Ho (2006) studied the effectiveness of the process approach to writing in six Hong Kong primary classrooms and the results of his study showed that the writing program was successful on the whole as it helped to bring about positive changes in most students' attitudes towards writing and improvements in their writing habits.

Also, Grossmann (2009) conducting a research on process approach, suggest that "the process approach is essential to exam success as long as students learn to use those skills, quickly and alone.” (p. 16). Demire (2011) studied process approach to overcome student anxiety and stated that in order to decrease student anxiety, which is a very common problem in academic writing classes, using a step by step implementation of the process approach with revision, rewriting and peer feedback practices, could yield positive results. After a long time, some studies were conducted by Bayat, Puengpipattrakul, and Alodwan and Ibnian in 2014. Bayat (2014) studied the effect of process approach on writing success and anxiety. The participants in this study were 74 first-year pre-school teaching students; a pretest-posttest control group quasi-experimental design was employed. Analyzing the obtained data showed that the process approach improved participants' success in writing and decreased the writing anxiety to a statistically significant extent.

In the same line, Puengpipattrakul (2014) studied process approach to writing to develop Thai EFL students' socio-cognitive skills on 24 first-year Thai undergraduate students from the Faculty of Sports Science in a university in Bangkok, Thailand. His findings indicated that the process-approach instructions helped develop students' socio-cognitive skills and led to participants' positive attitudes toward writing. Affirming the previous studies, Alodwan and Ibnian (2014) investigated how effective process writing is in developing 90 university students' essay writing skills in EFL. They showed that the process approach to writing had positive affect on the students' essay writing skills in EFL. So the researchers recommended placing more emphasis on teaching writing as a process not only as a product. Similarly, Gül Özenç (2016) researched the effect of process-oriented writing activities on the achievement and attitude of the pre-service primary school teachers and indicated that the process writing exercises were highly influential in terms of improving achievement and attitude of pre-service primary school teachers (p. 227).

In examining the process approach, some of the researchers studied the advantages of this approach and mentioned their opinions and outcomes. Onozawa (2010) examined the value of the process approach by considering its history, its advantages and disadvantages, and also by utilizing it in his classes. His findings demonstrated that the process approach is useful for both teachers and learners because there are various textbooks available and many teachers who have incorporated the approach for writing classes. A year after him, Ghosal (2011) by comparing the writing samples of students who were taught with specific activities in the process approach to those who were taught with more traditional approaches, found that the process approach has a very significant impact: The main benefit of the process approach seems to be that it treats specific writing 
Ghobadi, M.

difficulties. In the same vein, Al-Sawalha (2014) investigated potential advantages of process writing for students English language and literature at Jerash University in Jordan and stated that the process approach to writing has the potential to address some of the significant problems faced by the students and teachers.

Comparison of product and process approaches - Some of the studies compared the effect of the two approaches and represented their results. Such as Frans (2010) who analyzed the effect of teaching writing using process-based approach and product-based approach on the quality of SMA students' hortatory writing and concluded that there was no considerable difference on the writings of students who were taught with process approach and the students who were taught with product approach. He believed that this result "was caused by students' low skill and unfamiliarity to English and the short duration of experiment." (p. 103).

Similarly, Shahrokhi Mehr (2017) told that process approach had significant impact on EFL learners' writing performance and also it had positive effect on EFL learners' attitude toward writing skill. This study suggested that "in order to develop the EFL learners' writing skill, the EFL instructors can insert the process based approach in syllabus design" (p. 158). In the same vein, Palpanadan et al. (2014) investigated comparative analysis of process versus product approach of teaching writing in Malaysian schools. Their findings showed that teachers prefer to use product approach due to its easy application and avoid process approach due to its being time-consuming. However, they came to conclude that instead of using either product or process approaches in isolation; teachers should blend both approaches and use them according to the demand of situation and nature of learners and their learning styles. Thus, the suggestion of designing activities by blending the process approach with product approach will be more effective rather than selecting one approach. (p. 794).

Teachers' attitudes towards a writing approach can either pave the teaching way or stand in the way of the teaching. Also the learners' attitudes towards the teaching method and approach play an important role in improvement of their writing abilities. This research can help design instructional programs by discovering the learners' and teachers' ideas towards the two approaches in writing. Also, it can help teachers find effective ways and appropriate strategies to overcome barriers of teaching writing. So, it leads to a more efficient teaching strategy and approach regarding teaching writing. As a result, writing ability of students will be improved.

This study proposed a suitable approach in writing to be applied in Iranian writing contexts by exploring the Iranian EFL learners' and teachers' attitudes towards the two approaches, product and process approaches. To achieve the above-mentioned goals, the following research questions were posed in this study:

$>\quad$ How do Iranian EFL teachers perceive product approach to writing?

How do Iranian EFL teachers perceive process approach to writing?

$>\quad$ How do Iranian EFL student writers perceive product approach to writing?

$>\quad$ How do Iranian EFL student writers perceive process approach to writing?

\section{Method}

The study was conducted in Caspian Language Institute in Shiraz. All the four language skills had been heeded from the beginning. Although the main focus was on speaking, writing had its position in teaching English in this institute. Different books were selected to teach English for different levels of proficiency. "English Result", which had four series of books was taught to learners of intermediate level. Each book was taught during four semesters in nearly nine months. This study lasted for about six months, starting from October 2017 and in March 2018.

Participants - The participants of this study come in two groups: 92 EFL learners and 25 teachers from Caspian Language Institute in Shiraz. All the learners were at intermediate level of language proficiency. The age of the learners ranged between 15 and 22. All participants were Iranian students with Persian as their mother 
An investigation of EFL teachers' and learners' attitudes towards product and process approaches to writing

tongue. The participants were from both genders. Forty-five of the learners were male and forty-seven of them were female. It should be mentioned that it was assigned to have 100 learners to respond the questionnaires, but 8 of them did not return them back. Most of the learners had studied English in Language Institutes for 2-3 years. Five of them were studying English in the university, beside studying in Language Institutes. Most of the teachers (23 persons) were professionals who had taught English for 4-10 years and had taught writing for 3-8 years. Two teachers had experience in teaching English for three years. Majority of the teachers (14 persons) were females and 11 males. Their age ranged from 25 to 44 . It is worth mentioning that all participants took part in the study with full consent.

Materials - In order to conduct the present study and also to gain more accurate results, two major instruments were used: an interview and a set of two questionnaires.

Structured Interviews - In the first phase of this study the interviews were conducted. To discover the participants' ideas regarding the two approaches, the researcher selected 10 teachers and 10 learners randomly and interviewed them individually and face-to-face. Before the interviews, the interview items had been written down for the ease of conducting. In other words, the interviews were structured. Questions were open-ended to let the interviewees add and explain any extra point. The interviewees answered 13 questions regarding their ideas to writing and its approaches. This took five sessions. Interviews were conducted in Persian to avoid any negative effect of differing language ability of the participants. Each interviewee answered the questions during 10 to 15 minutes.

Questionnaires - The second phase of conducting the study was developing the needed questionnaires to measure teachers ' and learners' attitudes towards product and process approaches. So, upon an extensive literature review and analyzing the interviews of the participants, the researcher developed a set of two 5-point Likert-scale questionnaires (one for teachers and one for learners) to investigate the participants' attitudes toward the two approaches. Teachers' questionnaire is composed of 20 items in a 5-point Likert scale from 1 (strongly agree) to 5 (strongly disagree). The items of this questionnaire were categorized into three categories: general features of writing ( 2 items), features of product approach ( 8 items), and features of process approach (10 items) (See Appendices C). Learners' questionnaire contained 23 items just like the teachers' scale. The items of this questionnaire were also categorized into three categories: general question ( 3 items), features of product approach (10 items), and features of process approach (10 items).

Reliability - After piloting the questionnaires with 20 learners and 5 teachers, Cronbach Alphas of the questionnaires were computed to establish the reliability. The Cronbach Alpha of the teachers' questionnaire was found out to be .73 when it was piloted. While, the Cronbach Alpha of learners' questionnaire was computed to be .76 .

Procedures - The sample of the study consisted of 100 intermediate language learners ( 8 of whom did not return the questionnaires) and 25 teachers who were selected using convenience sampling from Caspian Language Institute in Shiraz. The researcher used convenience sampling because the participants were in access according to Dornyie (2003) convenience sampling is used when members of the target population meet certain practical criteria, such as geographical proximity, availability at a certain time, or easy accessibility. And also it is used when participants have certain features that are related to the purpose of the study.

\section{Results}

The main objective of the present study is to determine how Iranian EFL learners and teachers perceive two approaches (i.e. product and process) in writing. For developing the questionnaires, interviews with some of the participants were needed. Therefore, the next section, reports the results of the interviews with ten teachers and ten learners. 


\subsection{Results of the interviews}

Upon an extensive literature review and in order to develop the questionnaire, it was considered to gain a deeper insight into the participants' attitudes towards the two approaches. So, the researchers conducted interviews with some of the participants. Among the participants, 10 teachers and 10 learners were selected and they answered 13 questions. The questions considered three categories: real writing context of the participants, participants' ideas about features of product approach and participants' ideas about different aspects of process approach. Based on the participants' responses, the following categories emerged from the data:

\section{$\underline{\text { Learners' responses }}$}

Interest in writing - Majority of the participants were interested in writing. They considered writing useful and important in language learning. As an example, one of the learners mentioned:

Writing is very important. Since I am a college student and sometimes it is needed to write a text in English. I become so ashamed to have many mistakes in my text. So, I should learn how to write.

Time allotted for teaching writing - Most of the learners believed that the time of teaching writing is not sufficient and they wanted eagerly more time to be allocated to teaching of writing. They stated that in 20 or 30 minutes learning of writing cannot really occur and it needs more time to be taught step by step.

Eagerness in group writing - Learners were interested in writing in groups. They believed that group work results in their writing improvement, because all members of a group use knowledge and experience of each other, correct mistakes of each other, and hence write better texts. Thus, these lead to improvement in their writing and motivate them to learn writing.

Thinking before writing - Most of the learners wished to have enough time to think about topic, structure and audience before they start to write. They explained that it is a need to think about some essential issues before starting to write a text. Majority of them agree that they can think a bit about topic but they do not have enough time to think about the other necessary elements before writing a text. Some of them state that when we think of our audience, it absolutely affects our writing.

Learners' willingness to processes of writing - Many of the learners were interested in processes of writing. One of them stated that "although presenting a model is a good method and gives us a pattern to write correctly, we are interested to learn processes of writing". They believed that if processes of writing be taught, significant improvement will be made in their writing.

\section{$\underline{\text { Teachers' responses }}$}

Time allotted for teaching writing - Similar to learners, majority of the teachers believed that the time dedicated to teaching writing is not enough and it is needed that the curriculum planners reconsider the needed time in textbooks.

Common method of teaching writing - When the teachers were asked to explain their teaching method of writing, most of them noted that first they explain the related grammar, then the grammar is exemplified within a text and finally, they ask the learners to write a similar text. They emphasized that the final text of learners should be as correct as possible.

Different views to product and process approaches - Most of the teachers mentioned that product approach is easy to teach and it is not time- consuming. On the other hand, they believed that process approach is suitable for learners at intermediate and advanced levels of proficiency, provided that the needed time be considered in textbooks. Also, they mentioned that teaching writing by presenting a model is good for beginner learners. The findings of the interview showed that teachers considered both the process and product approaches suitable in

52 Consortia Academia Publishing (A partner of Network of Professional Researchers and Educators) 
An investigation of EFL teachers' and learners' attitudes towards product and process approaches to writing

different context.

\subsection{Results of administering the questionnaires}

The analysis of data was mainly quantitative and it used a set of two questionnaires for its purpose. The questionnaires consisted of some categories each addressing different features of the two approaches to writing. It should be mentioned that since the main focus here was on the larger patterns of agreement and disagreement and degrees of ideas were in the second place of importance, the two categories of strongly agree/agree and strongly disagree/disagree were merged to simply agree and disagree categories. Here, the items which directly targeted the research questions were separately analyzed. The researcher used the descriptive statistics to investigate the participants' attitudes toward the approaches.

\section{Results of the teachers' questionnaire}

This questionnaire contained 20 items. Table 2 below summarizes the structure of the questionnaire. The first group of items aimed to investigate the respondents' opinions in relation to general features of writing approaches. The second group of items explored the participants' views towards features of product approach and finally last group of items examined the participants' attitude towards features of process approach.

\section{Table 2}

General structure of teachers' questionnaire

$\begin{array}{ll}\text { Category 1: General features } & \text { Items: } 2,10 \\ \text { Category 2: Features of product approach } & \text { Items: } 1,4,5,6,11,15,16,19 \\ \text { Category 3: Features of process approach } & \text { Items: } 3,7,8,9,12,13,14,17,18,20\end{array}$

Analysis of category 1 - Items 2 and 10 belong to this category and the following table shows the results:

Table 3

Analysis of items in category 1 of the questionnaire

\begin{tabular}{lccc}
\hline \multicolumn{1}{c}{ Items } & Agree (\%) & Disagree (\%) & Not Sure (\%) \\
\hline $\begin{array}{l}\text { Item 2: selection of teaching method should be in } \\
\text { accordance with the proficiency level of the learners. }\end{array}$ & 100 & 0 & 0 \\
$\begin{array}{l}\text { Item 10: learners' attitudes towards the teaching method } \\
\text { affect their learning of writing. }\end{array}$ & 76 & 0 & 24 \\
\hline
\end{tabular}

Based on Table 3, 100 percent of the teachers agreed with item 2 and 76 percent of them agreed with the item 10. So, all the teachers agreed that proficiency level of the learners should be considered in selecting a teaching method and learners' attitudes towards the teaching method affect their learning of writing (Q10).

Analysis of category 2 - Items 1, 4, 5, 6, 11, 15, 16, and 19 belong to this category. These items answer the first research question: How do Iranian EFL teachers perceive product approach to writing? The following table shows the results. As can be seen in Table 4, most of the teachers agreed with nearly all features of product approach, except items 16 and 11. However, results of item 16 implies teachers agree that the final text in writing is not more important than processes of writing and item 11 (64\% not sure) shows that they are not sure whether teaching with product approach is easier than process one or not. This table also indicates that most of the teachers agreed that the final texts are important because it is an indication of degree of writing learning. According to Table 4, teaching grammar is necessary in teaching writing, and learners' errors should be corrected by teachers, since it leads to flawless texts (76\% item15 and 60\% item19). As the Table implies, teaching writing by presenting a model affects the writing improvement of the beginner learners $(76 \%$, item6). In a nutshell, by computing the mean of agreement percentage, it can be elicited that $61 \%$ of teachers have positive attitude toward product approach. 
Ghobadi, M.

\section{Table 4}

Descriptive statistics of the teachers' attitudes towards features of product approach

\begin{tabular}{|c|c|c|c|}
\hline Items & Agree (\%) & Disagree $(\%)$ & Not Sure (\%) \\
\hline $\begin{array}{l}\text { Item1: In teaching writing, firstly the related grammar } \\
\text { should be taught. }\end{array}$ & 84 & 16 & 0 \\
\hline $\begin{array}{l}\text { Item 4: The final text indicates how much the learners } \\
\text { learn writing. }\end{array}$ & 84 & 0 & 16 \\
\hline $\begin{array}{l}\text { Item 5: Special attention should be given to final text in } \\
\text { teaching writing. }\end{array}$ & 72 & 20 & 8 \\
\hline $\begin{array}{l}\text { Item 6: Presenting a model has a good effect on writing } \\
\text { improvement of beginner learners. }\end{array}$ & 76 & 4 & 20 \\
\hline $\begin{array}{l}\text { Item 11: Teaching with product approach is easier than } \\
\text { process one. }\end{array}$ & 28 & 8 & 64 \\
\hline $\begin{array}{l}\text { Item 15: Correcting the grammar errors leads to more } \\
\text { flawless texts. }\end{array}$ & 76 & 12 & 12 \\
\hline $\begin{array}{l}\text { Item 16: Final text in writing is more important than } \\
\text { processes of writing. }\end{array}$ & 8 & 68 & 24 \\
\hline $\begin{array}{l}\text { Item 19: If teacher roles as a corrector, writing will be } \\
\text { learnt better. }\end{array}$ & 60 & 20 & 20 \\
\hline
\end{tabular}

Analysis of category 3 - Items 3,7,8,9,12,13,14,17,18 and 20 belong to this category and these items answer the second research question asking how Iranian EFL teachers perceive process approach to writing. Table 5 shows the results:

\section{Table 5}

Descriptive statistics of the teachers' attitudes towards features of process approach

\begin{tabular}{|c|c|c|c|}
\hline Items & Agree (\%) & Disagree (\%) & Not Sure $(\%)$ \\
\hline $\begin{array}{l}\text { Item 3: In teaching writing, explaining the processes of } \\
\text { writing leads to better improvement of learners. }\end{array}$ & 100 & 0 & 0 \\
\hline $\begin{array}{l}\text { Item 7: Teaching with the process approach needs more } \\
\text { time to be allocated to it. }\end{array}$ & 32 & 40 & 28 \\
\hline $\begin{array}{l}\text { Item 8: Teaching with the process approach has effects on } \\
\text { improvement of intermediate learners. }\end{array}$ & 84 & 0 & 16 \\
\hline $\begin{array}{l}\text { Item 9: Teaching with the process approach is } \\
\text { time-consuming and boring. }\end{array}$ & 16 & 68 & 16 \\
\hline $\begin{array}{l}\text { Item 12: Teaching with the process approach leads to more } \\
\text { improvement in learners' writing than teaching with } \\
\text { presenting a model. }\end{array}$ & 72 & 0 & 28 \\
\hline $\begin{array}{l}\text { Item 13: Processes of writing such as planning, drafting, } \\
\text { and ... Should be explained to learners. }\end{array}$ & 92 & 8 & 0 \\
\hline $\begin{array}{l}\text { Item 14: If learner thinks about topic and audience before } \\
\text { starting to write, he/she will write better texts. }\end{array}$ & 100 & 0 & 0 \\
\hline $\begin{array}{l}\text { Item 17: Grouping the learners while teaching writing } \\
\text { causes anarchy. }\end{array}$ & 28 & 72 & 0 \\
\hline $\begin{array}{l}\text { Item 18: Grouping the learners while teaching writing } \\
\text { leads to writing better texts. }\end{array}$ & 72 & 0 & 28 \\
\hline $\begin{array}{l}\text { Item 20: If teacher roles as a facilitator, writing will be } \\
\text { learnt better. }\end{array}$ & 64 & 12 & 24 \\
\hline
\end{tabular}

This table demonstrates that majority of the teachers agreed with the features of process approach. Disagreements can be seen in items 7(40\%), 9(68\%), and 17(72\%). Regarding items 7 and 9 it should be mentioned that these two items consider issue of time. Disagreement with these items means that the teachers concur that process approach is not time-consuming. Disagreement with item 17 reveals that they believe that grouping the learners to write in groups does not lead to disorder. On the contrary, most of the teachers agreed that grouping the learners caused writing better texts (72\%, item18). According to Table 5, processes of writing such as planning, drafting, etc. should be explained to learners (92\%, item13), since it leads to better 
An investigation of EFL teachers' and learners' attitudes towards product and process approaches to writing

improvement in learners' writing (100\%, item3). As shown in Table 5, thinking about topic and audience before starting to write makes learners write better texts (100\%, item 14). Also, it is obvious in the Table that teaching with the process approach leads to more improvement in learners' writing than teaching by presenting a model (72\%, item 12). It is also suitable for intermediate learners ( $84 \%$, item 8). Facilitating role of the teacher also makes improvement in writing (64\%, item 20). Finally, by computing the mean of agreement percentage of features of process approach, $66 \%$ of teachers had a positive attitude toward process approach.

Results of the learners' questionnaire - This questionnaire contained 23 items and tried to give answer to third and fourth research questions. Table 6 below summarizes the information. Similar to teachers' questionnaire, first group of items investigated the respondents' opinions in relation to general features of writing approaches. The second group of items explored the participants' ideas towards features of product approach and finally last group of items presented the participants' attitude towards features of process approach.

\section{Table 6}

General structure of learners' questionnaire

\begin{tabular}{ll}
\hline Category 1: General features & Items: $1,2,8$ \\
Category 2: Features of product approach & Items: $9,10,11,12,16,18,19,20,21,23$ \\
Category 3: Features of process approach & Items: $3,4,5,6,7,13,14,15,17,22$
\end{tabular}

Analysis of category 1 - Items 1,2 and 8 belong to this category and the following table shows the results:

Table 7

Descriptive statistics of the learners' attitudes towards general questions

\begin{tabular}{|c|c|c|c|}
\hline Items & Agree $(\%)$ & Disagree $(\%)$ & Not Sure $(\%)$ \\
\hline $\begin{array}{l}\text { Item 1: In teaching a language, writing should also be } \\
\text { taught. }\end{array}$ & 94.5 & 3.3 & 2.2 \\
\hline Item 2: The time allocated to teaching writing is enough. & 31.5 & 42.4 & 26.1 \\
\hline $\begin{array}{l}\text { Item 8:Teaching writing in language classes needs more } \\
\text { time and explanation. }\end{array}$ & 71.7 & 12 & 16.3 \\
\hline
\end{tabular}

As can be seen in the above Table, $94.6 \%$ of the learners agreed item 1 which revealed their agreement that in language learning classes, writing should be also taught. Patterns of responses for item 2 (42.4\%) also shows that in students' views time dedicated to teaching writing is not sufficient. In the same line, $71.7 \%$ agreement in item 8 states that teaching writing needs more time and more explanation.

Analysis of category 2 - Items 9,10,11,12,16,18,19, 20, 21 and 23 belong to this category and these items answer the third research question asking about how Iranian EFL student writers perceive product approach to writing. The following table shows the results. Items 9,10,11 and 12 consider the putting emphasis on final texts. Based on Table 8, although putting emphasis on final text does not lead to stress (38\% disagreement, item 9) but it prevents creativity in writing (41.4\% agreement, item11). It is elicited from Table 8 that emphasis on final texts not only have effects on learning writing (43.4 disagreement, item 12), but also it does lead to learning of writing (44.6 agreement, item 10). Agreement percentage of items 16(93.4\%), 21(58.7\%) and $23(92.4 \%)$ show that teacher's error correction is needed in writing improvement. Agreement percentage of item 18 (45.7\%) and disagreement percentage of item 19(37\%) also indicate that although grammar is more important than content, only knowing grammar does not lead to learning writing. It should be mentioned that 56.5 percent of learners are not sure in this regard. In the same line, it can be inferred that copying a model of writing can improve their writing (57.6 agreement, item 20). It is worth mentioning that two of the learners did not answer item 19 and one of the learners did not answer item 20. On the whole, patterns of responses showed that learners' attitude to product approach was a mixture of traditional views on writing which they had experienced in their language learning classes and also new process perspectives which they were theoretically aware of. 
Ghobadi, M.

\section{Table 8}

Descriptive statistics of the learners' attitudes towards features of product approach

\begin{tabular}{|c|c|c|c|}
\hline Items & Agree $(\%)$ & Disagree $(\%)$ & Not Sure $(\%)$ \\
\hline Item 9: Emphasis on final text in writing leads to stress. & 29.4 & 38 & 32.6 \\
\hline $\begin{array}{l}\text { Item 10: Emphasis on final text in writing leads to learning } \\
\text { of writing. }\end{array}$ & 44.6 & 16.3 & 39.1 \\
\hline $\begin{array}{l}\text { Item 11: Emphasis on final text in writing hinders creation } \\
\text { in writing. }\end{array}$ & 41.4 & 20.6 & 38 \\
\hline $\begin{array}{l}\text { Item 12: Emphasis on final text in writing has no effect on } \\
\text { learning writing. }\end{array}$ & 20.7 & 43.4 & 35.9 \\
\hline $\begin{array}{l}\text { Item 16: If teachers correct the learners' errors, the learners } \\
\text { learn writing better. }\end{array}$ & 93.4 & 5.5 & 1.1 \\
\hline Item 18: Grammar is more important than content. & 45.7 & 23.9 & 30.4 \\
\hline $\begin{array}{l}\text { Item 19: Just learning the grammar has no effect on } \\
\text { learning writing. }\end{array}$ & 34.8 & 37 & 26.1 \\
\hline $\begin{array}{l}\text { Item 20:Copying a model causes us to write more correct } \\
\text { texts. }\end{array}$ & 57.6 & 30.5 & 10.9 \\
\hline $\begin{array}{l}\text { Item 21: If teacher roles as a corrector, writing will be } \\
\text { learnt better. }\end{array}$ & 58.7 & 13.1 & 28.2 \\
\hline $\begin{array}{l}\text { Item 23: Correcting grammar errors makes us write the } \\
\text { next texts without mistakes. }\end{array}$ & 92.4 & 3.3 & 4.3 \\
\hline
\end{tabular}

Analysis of category 3 - Items 3,4,5,6,7,13,14,15,17 and 22 belong to this category and these items probed student writers' views to process approach. The following table shows the results.

\section{Table 9}

Descriptive statistics of the learners' attitudes towards features of process approach

\begin{tabular}{|c|c|c|c|}
\hline Items & Agree $(\%)$ & Disagree $(\%)$ & Not Sure $(\%)$ \\
\hline $\begin{array}{l}\text { Item 3: Teaching with the process approach leads to more } \\
\text { improvement in learners' writing than teaching with } \\
\text { presenting a model. }\end{array}$ & 77.2 & 8.7 & 14.1 \\
\hline $\begin{array}{l}\text { Item 4: Processes of writing such as planning, drafting, } \\
\text { and ... Should be explained to learners. }\end{array}$ & 76.1 & 4.3 & 19.6 \\
\hline $\begin{array}{l}\text { Item 5: Teaching with the process approach is } \\
\text { time-consuming and boring. }\end{array}$ & 25 & 43.5 & 31.5 \\
\hline $\begin{array}{l}\text { Item 6: Thinking about topic before starting to write affects } \\
\text { the improvement of writing. }\end{array}$ & 98.9 & 1.1 & 0 \\
\hline $\begin{array}{l}\text { Item 7: Thinking about audience before starting to write } \\
\text { affects the improvement of writing. }\end{array}$ & 64.1 & 9.8 & 26.2 \\
\hline $\begin{array}{l}\text { Item 13: Before starting to write, it is needed to think about } \\
\text { content. }\end{array}$ & 91.3 & 6.5 & 2.2 \\
\hline $\begin{array}{l}\text { Item 14: Before starting to write, it is needed to think about } \\
\text { structure. }\end{array}$ & 95.6 & 3.3 & 1.1 \\
\hline $\begin{array}{l}\text { Item 15: Before starting to write, it is needed to think about } \\
\text { audience. }\end{array}$ & 59.8 & 9.8 & 29.3 \\
\hline Item 17: Group work in writing improves writing. & 52.2 & 19.5 & 28.3 \\
\hline $\begin{array}{l}\text { Item 22: If teacher roles as a facilitator, writing will be } \\
\text { learnt better. }\end{array}$ & 67.4 & 6.5 & 26.1 \\
\hline
\end{tabular}

Results of analyzing the questionnaire items showed that teaching with process approach leads to more writing improvement in comparison with product approach $(77.2 \%$, item 3$)$ and stages of process approach should be explained for learners $(76.1 \%$, item 4$)$. Item 5 which claimed that process approach is time-consuming and tedious showed that 43.5 percent of the learners disagree and 31.5 percent doubted the point. Based on results of Table 9 , it is needed to think about topic (98.9\%, item6), audience $(64.1 \%$, item 7 and $59.8 \%$, item 15$)$, content $(61.3 \%$, item 13$)$ and structure $(95.6 \%$, item14) before starting to write. Computing the agreement percentage mean $(81.94 \%)$, shows that the learners should be given enough time to think about these issues 
An investigation of EFL teachers' and learners' attitudes towards product and process approaches to writing

before starting to write a text. It should be noted that one of the learners (1.1\%) did not answer item 15 . According to the results of item 17, 52.2\% of learners agree group writing and $28.3 \%$ of them are not sure in this regard. Also, $67.4 \%$ of the learners agreed that if the teacher's role be facilitator, writing will be learned better.

\section{Discussion}

The present study explored the attitude of teachers and learners to product and process approaches to writing. For this aim, interviews and a set of two questionnaires were employed to assess how learners and teachers considered the effects of product and process approaches on writing improvement. The results of the statistical analyses revealed that majority of both groups held more favorable attitude toward process approach. A discussion of findings is presented for each of the research questions details below.

The first research question of the study was how do Iranian EFL teachers perceive product approach to writing? Based on data analysis of category 2 (see Table 4), more than half of the teachers held positive attitude towards product approach (Agreement Percentage Mean $=61$ ). The teachers agreed that grammar is an inseparable part of teaching writing and it should get enough attention while teaching writing $(\mathrm{AP}=84)$. Nearly most of the teachers mentioned that error correction is a necessary element of teaching writing and it helps the learners to write more correct texts( $\mathrm{AP}=76)$. The present findings confirm the previous studies (Palpanadan et al., 2014). According to Palpanadan et al. (2014), since the focus of writing lesson falls mostly on the correct sentence structure that complements the grammar lesson, there is an opportunity for students for correction of mistakes and learn the correct grammar and sentence structure by looking at the teacher's marking. However, some researchers had reached to reverse conclusions and stated that the idea of confronting the errors leads to a certain amount of tension for the student (Graves, 1994; Özbay \& Zorbaz, 2011; Routman, 1996). So, it discomfits the learning of writing. Beside the agreements on most of features of product approach, majority of teachers stated that this approach best fits for beginner learners not for learners with higher language proficiencies(AP=76). The present findings confirm the Hasan and Akhand's (2010) study which concluded that providing a model will be helpful to the students with low proficiency level.

It can be highlighted that teaching grammar, error correction, and emphasis on final text are among key features of product approach which attracted the attention of this group of the respondents.

The second question of the study was how do Iranian EFL teachers perceive process approach to writing? Results of the questionnaire showed that process approach is not time-taking and the processes of writing should be taught to the learners. Writing in groups can have positive effects on the learners' writing improvement. It can be inferred that this approach is applicable for learners at intermediate level of language proficiency $(\mathrm{AP}=84)$ which is in line with Grossmann's (2009) findings. He mentioned that process approach is suitable at higher levels but at lower levels product or genre approaches would be more useful.

Based on data analysis of category 3 (see Table 5), the results showed that most teachers perceived process approach positively (APM=66). This finding is in line with Gül Özenç (2016) who found that the process writing exercises highly influenced the attitude of pre-service primary school teachers. In a similar vein, third research question of the study was how do Iranian EFL student writers perceive product approach to writing? Findings showed that most of the learners agree that final text is an important factor of writing and putting stress on it makes them better writers with flawless texts. However, they believed that overemphasis on final product in teaching by presenting a model hinders the learners' creativity. This is in line with Chang and Szanajda (2016) who stated that in product approach the students' writing creativity might be confined to the model articles provided and their writing might be limited to the contents of the model articles.

It can be elicited from Table 8 that learners perceive product approach positively but their views to product approach was a mixture of traditional views on writing which they had experienced in their language learning classes and new process perspectives which they were theoretically aware of. 
The last research question was how do Iranian EFL student writers perceive process approach to writing? Based on the results of Table 9, the learners believed that every writing task should be pre-planned. In fact, they should be given time to think about topic, audience, content and structure before starting to write a text. This confirms Lima's (2015) findings which mentioned that giving students time to process their information and ideas is necessary. The results also showed that learners agree that writing in groups makes improvement in their writing. This result is also in line with Storch (2005) study who studied students' reflections on product and process approaches to writing. Interviewing with the students in the days immediately following the class, he stated that all students were positive about group and pair work. In the same line, Dernoun (2015) mentioned that collaborative writing, in pairs or in groups, is of great effectiveness and provides cognitive help for students. Students have to be encouraged to share their writing with each other. The results of Puengpipattrakul's (2014) study pointed out that group writing could at least motivate and blend classroom learning with real-life learning. Also, Donato $(1988,1994)$ mentioned that group/pair work in collaborative writing may encourage a pooling of knowledge about language. Similarly, the study by Sadaghian (2016) on process approach confirmed that process approach is exciting because of collaboration. The participants in her research also found that the process writing was not that difficult and collaboration facilitated it. Also, students in her study thought of process writing as a chance to contribute more to their own text and writing. This result is in contrary to results of McCarthey and McMahon (1992) which concluded that students in group writing have no ownership of their written text and thus little power to effect change.

To sum, it can be concluded that most of the learners perceived process approach positively. The findings of this question confirms the previous studies. For example, Ho (2006) studied the effectiveness of the process approach to writing in six Hong Kong primary classrooms and the results of his study showed that the writing program was successful on the whole as it helped to bring about positive changes in most students' attitudes towards writing and improvements in their writing habits. Shahrokhi Mehr (2017) also conducted a study on the impact of product and process approaches on Iranian EFL learners' writing ability and their attitudes toward writing skill on 60 Iranian language learners. The result showed that process approach had significant impacts on EFL learners' writing performance. It also had positive effects on EFL learners' attitude toward writing skill. Similarly, Sadaghian (2016) investigated process approach in EFL classes and concluded that students held positive attitudes and were more comfortable with process writing in production of their final text. Puengpipattrakul (2014) studied a process approach to writing to develop Thai EFL students' socio-cognitive skills. He found that the process-approach instructions led to the participants' positive attitudes toward writing. So that the extracts from the content analysis of the interview responses of participants showed that they all agreed that the process approach to writing instructions could develop their socio-cognitive skills and they could learn how to write systematically from their teacher and classmates.

\section{Conclusion and implications}

The findings of the present study pointed to some general conclusions regarding the attitudes of teachers and learners towards product and process approaches to writing in Iran. Firstly, all the teachers used product approach in their teaching writing just because of the ease of applying this approach. As Palpanadan et al. (2014) believed, teachers prefer to use product approach due to its easy application and ease of their task in introducing essays of many types that could help them to cover the syllabus on time and avoid process approach due to its being time-consuming. Although they used this approach and held positive attitude toward it, they were willing to make use of the process approach in their classes provided that the needed time be allocated in both textbooks and courses. Also, it is concluded that writing has been taught with product approach in writing classes without considering any place for the views of learners and also teachers as important stakeholders in the learning process. Thus, the writing proficiency level of the learners was not satisfactory. This study filled this gap by investigating the learners' and teachers' ideas toward the two approaches to writing.

Findings of the study also showed that there is a pressing need for teacher training courses in the country. The over-emphasis on formatting and mechanical features of writing among the teachers showed that they had a

58 Consortia Academia Publishing (A partner of Network of Professional Researchers and Educators) 
An investigation of EFL teachers' and learners' attitudes towards product and process approaches to writing

limited conception of the writing construct. All the teachers saw writing in teaching grammar and mechanical features of writing. So, there is a need to train them new and better methods of teaching writing.

\subsection{Implications}

Theoretical implications - Theoretically, this study enriches the literature on teaching writing in Iranian EFL context since there is no study existing in Iranian about the teachers' and learners' attitudes about the use of the product and process approaches to writing. So, the first theoretical implication of this study is its contribution to EFL writing questionnaire development literature. In this study, criteria for developing the questionnaires were directly obtained from the teachers' and learners' cognitions regarding the two approaches.

Pedagogical implications - Awareness of the teachers' and students' attitudes to product and process approaches to writing can lead to a number of applied goals as the following:

The first practical implication of the current study relates to teacher training. Training novice teachers with realities of the Iranian EFL context will lead to teachers' professional development. Although the process approach was not trialed at a large level with teachers in the country, the evidence from the interviews and questionnaire showed that the teachers on the whole had a positive view to the approach. Second implication is improving the writing programs. The syllabus designers can improve writing programs by allocating enough time to teaching the preferred approach. Third implication of exploring the teachers' and learners' attitude towards the two approaches is improvement in teaching writing textbooks by considering the materials and activities fitted with the learners' and teachers' opinions in writing. When writing programs and textbooks improved, absolutely the writing assessment programs will be revised and improved to meet the goals of writing courses. Fourthly, the learners will be aware of the realistic expectations of their achievement. Another implication of this study is providing the curriculum planners and course instructors with suitable strategies and approaches for developing students' essay writing skills in EFL contexts. Last but not the least, curriculum planners can use the findings of this study to consider the teachers' and students' particular styles in the preparation of the writing courses. Therefore, the results of the study seem pedagogically applicable for the language learners, language teachers, teacher's trainers and even for syllabus designers.

Acknowledgments: First of all, I would like to express my sincere gratitude to my reviewer Dr. Ghanbari for the continuous support of my study. I'm also grateful to my husband for his patience, motivation, financial support, and immense knowledge he gave me. Last but not least, I would like to thank my parents, especially my mother for supporting me spiritually throughout my life. I can't end without thanking my lovely little girl, Aylin, who is really the pride of my life. The current article was extracted from my master thesis which was approved by the approval committee of Boushehr Azad University. Regarding the availability of data, I should say that all the questionnaires were on papers and hard copies. Interviews were recorded and then transcribed on papers. After the university approval, I decided not to hold the papers anymore. It should be mentioned that this study is funded fully by my husband. Since it is extracted from my own thesis, it has no conflict with any person or institute interests.

\section{References}

Aiken, L. (1996). Rating scales and checklists: Evaluating behavior, personality, and attitudes. John Wiley. Allport, G. W. (1935). Attitudes. In C. Murchinson (Ed.), Handbook of social psychology (pp. 810-823). Clark University Press.

Alodwan, T. A. A., \& Ibnian, S. S. Kh. (2014). The effect of using the process approach to writing on developing university students' essay writing skills in EFL. Review of Arts and Humanities, 3(2), 139-155.

Al-Sawalha, A. M. (2014). Potential advantages of process writing for students English language and literature at Jerash University in Jordan. International Journal on Studies in English Language and Literature, 6(2), 
Ghobadi, M.

41-46.

Alsouqi, S. (2001). The effect of using computers in teaching of L2 composition on the writing performance of tenth grade students in Amman private schools [Unpublished masteral thesis, University of Jordan]. Amman, Jordan.

Bayat, N. (2014). The effect of the process writing approach on writing success and anxiety. Educational Sciences: Theory \& Practice, 14(3), 1133-1141. https://doi.org/10.12738/estp.2014.3.1720

Badger, R., \& White, G. (2000). A process genre approach to teaching writing. ELT Journal, 2(54), 153-160. https://doi.org/10.1093/elt/54.2.153

Berlin, J. A. (1988). Rhetoric and ideology in the writing class. College English, 50, 477-494. https://doi.org/10.2307/377477

Bereiter, C., \& Scardamalia, M. (1987). The psychology of written composition. Lawrence Erlbaum Associates.

Chang, W., \& Szanajda, A. (2016). How computer technology transforms writing performance: An integration of the process/genre approach and blogs in EFL writing courses. International Journal for 21st Century Education,1(3), 169-185. https://doi.org/10.21071/ij21ce.v3iSpecial.5715

Dernoun, H. (2015). Students' attitudes towards academic writing: challenges facing EFL learners [Unpublished masteral thesis, Mohamed Kheider University]. Biskra.

Demire, E. (2011). Take it step by step: Following a process approach to academic writing to overcome student anxiety. Journal of Academic Writing, 1(1), 222-227. https://doi.org/10.18552/joaw.v1i1.28

Dornyei, Z. (2003). Questionnaires in second language research: Construction, administration, and processing. Lawrence Erlbaum Associates.

Donato, R. (1994). Collective scaffolding in second language learning. In J. P. Lantolf, \& G. Appel (Eds.), Vygotskian approaches to second language research (pp. 33-56). Ablex.

Donato, R. (1988). Beyond group: A psycholinguistic rationale for collective activity in second-language learning [Unpublished doctoral dissertation, University of Delaware]. Newark.

Frans, H. J. G. (2010). The effect of teaching writing using process-based approach and product-based approach on the quality of SMA students' hortatory writing. Magister Scientiae, 28, 103-113.

Gül Özenç, E. (2016). The effect of process oriented writing activities on the achievement and attitude of the preservice primary school teachers. Journal of Education and Training Studies, 11(4), 227-237. https://doi.org/10.11114/jets.v4i11.1736

Ghosal, M. (2011). Process writing. Centre for English Language Studies, 2, 1-24.

Grossmann, D. (2009). Masters in teaching English as a foreign or second language; Process approach to writing [Unpublished Master thesis, University of Birmingham]. Birmingham.

Grabe, W., \& Kaplan, R. B. (1996). Theory and practice of writing: an applied linguistic perspective. Longman.

Graves, D. H. (1994). A fresh look at writing. Portsmouth: Heinemann.

Hasan, M. K., \& Akhand, M. M. (2010). Approaches to writing in EFL/ESL context: Balancing product and process in writing class at tertiary level. Journal of NELTA, 15(1-2), 77-88.

https://doi.org/10.3126/nelta.v15i1-2.4612

Ho, B. (2006). Effectiveness of using the process approach to teach writing in six Hong Kong primary classrooms. Working Papers in English and Communication, 17(1), 1-52.

Hyland, K. (2002). Teaching and researching writing. Longman.

Hayes, J., \& Flower, L. (1981). Identifying the organization of writing processes. In L. W. Gregg \& E. R. Steinberg (Eds.), Cognitive processes in writing (pp. 3-30). Lawrence Erlbaum Associates.

Johns, A. M. (1990). L1 composition theories: Implications for developing theories of L2 composition. In B. Kroll (Ed.), Second language writing: Research insights for the classroom (pp. 24-36). Cambridge University Press. https://doi.org/10.1017/CBO9781139524551.006

Kamimura, T. (2000). Integration of process and product orientations in EFL writing instruction. RELC Journal, 31(2), 1-28. https://doi.org/10.1177/003368820003100201

Lima, L. (2015). Adapting the process writing approach to English language learners with special needs: using visuals [ Unpublished masteral thesis, Bridgewater State University]. Massachusetts.

Manchón, R., \& Roca de Larios, J. (2007). Writing-to-learn in instructed language learning contexts. In E. Alcón

60 Consortia Academia Publishing (A partner of Network of Professional Researchers and Educators) 
An investigation of EFL teachers' and learners' attitudes towards product and process approaches to writing

Soler \& M. Safont Jordà (Eds.), Intercultural language use and language learning (pp. 101-121). Springer. https://doi.org/10.1007/978-1-4020-5639-0_6

McCarthey, S. J., \& McMahon, S. (1992). From convention to invention: Three approaches to peer interactions during writing. In R. Hertz-Lazarowitz \& N. Miller (Eds.), Interaction in cooperative groups: The theoretical anatomy of group learning (pp. 17-35). Cambridge University Press.

Nordin, Sh., \& Mohammad, N. (2006). The best of the two approaches: process/ genre-based approach to teaching writing. The English teacher, 5, 75-85.

Nunan, D. (1999). Second language teaching and learning. Heinle \& Heinle Publishers.

Olson, J. M., \& Maio, G. (2003). Attitudes in social behavior. In T. Million \& M. Cerneer (Eds.), Handbook of psychology: Personality and social psychology (Vol.5, pp. 229-329). Wiley. https://doi.org/10.1002/0471264385.wei0513

Onozawa, Ch. (2010). A study of the process writing approach: A suggestion for an eclectic writing approach. Research Note, 10, 153-163.

Özbay, M., \& Zorbaz, K. Z. (2011). Daly-Miller'ın Yazma Kaygısı Ölçeği’nin Türkçeye uyarlanması [Adaptation of Daly-Miller's Writing Anxiety Scale to Turkish]. Mustafa Kemal Üniversitesi Sosyal Bilimler Enstitüsü Dergisi, 8(16), 33-48.

Palpanadan, S. T., Bin Salam, A. R., \& Bte Ismail, F. (2014). Comparative analysis of process versus product approach of teaching writing in Malaysian schools: Review of literature. Middle-East Journal of Scientific Research, 22(6), 789-795.

Palpanadan, S. T., Bin Salam, A. R., \& Bte Ismail, F. (2014). How indispensable are model essays in Malaysian classrooms? Nationalism, Community Development and Ethnic Relation, 9, 109-116.

Pincas, A. (1982). Teaching English writing. Macmillan.

Puengpipattrakul, W. (2014). A process approach to writing to develop Thai EFL students' socio-cognitive skills. Electronic Journal of Foreign Language Teaching, 2(11), 270-284.

Rasuli, F. (2015). The effect of Van Dijk discourse strategies on Iranian EFL learners' writing proficiency [Unpublished Master thesis, Persian Gulf University]. Bushehr.

Routman, R. (1996). Literacy at the crossroads: Crucial talk about reading, writing, and other teaching dilemmas. Heinemann.

Raimes, A. (1983). Techniques in teaching writing. Oxford American English.

Shahrokhi Mehr, H. (2017). The impact of product and process approach on Iranian EFL learners' writing ability and their attitudes toward writing skill. International Journal of English Linguistics, 2(7), 158-166. https://doi.org/10.5539/ijel.v7n2p158

Sadaghian, Sh. (2016). A new approach toward process oriented writing Wikis in EFL classes [Unpublished doctoral thesis, Alzahra University]. Tehran.

Storch, N. (2005). Collaborative writing: Product, process, and students' reflections. Journal of Second Language Writing, 14, 153-173. https://doi.org/10.1016/j.jslw.2005.05.002

Silva, T. (1990). Second language composition instruction: developments, issues, and directions in ESL. In B. Kroll (Ed.), Second language writing: research insights for the classroom (pp. 11-23). Cambridge University Press. https://doi.org/10.1017/CBO9781139524551.005

Tribble, C. (1996). Writing. Oxford University Press.

Travers, M. W. (1973). Educational psychology. Macmillan.

Vanderpy, G. D. (2012). The process approach as writing instruction in EFL (English as a Foreign Language) classrooms. MA TESOL Collection, 545(1), 1-64.

Yi, J. (2009). Defining writing ability for classroom writing assessment in high schools. Journal of Pan-Pacific Association of Applied Linguistics, 13(1), 53-69.

Zamel, V. (1998). Strangers in academia: The experiences of faculty and ESL students across the curriculum. In V. Zamel \& R. Spack (Eds.), Negotiating academic literacies: Teaching and learning across languages and cultures (pp. 249-264). Lawrence Erlbaum Associates. 
Ghobadi, M.

62 Consortia Academia Publishing (A partner of Network of Professional Researchers and Educators) 